\title{
Dispositivo de feminilidade, juventudes e imagens de si como processos educativos e de socialização
}

\section{Femininity device, youth and images of the self as educational and socialization processes}

\section{Dispositivo de feminidad, juventud e imágenes del yo como procesos educativos y de socialización}

\author{
Nathalye Nallon Machado* \\ Anderson Ferrari ${ }^{* *}$
}

\section{Resumo}

O artigo é resultado de uma pesquisa na área da Educação, realizada com sete mulheres jovens, estudantes de uma escola pública, interessada na relação entre as imagens selfies - que são publicadas nas redes sociais. $O$ foco de análise diz dos dispositivos de feminilidade e juventude que são acionados e postos em circulação para a construção de imagens de si como mulheres jovens. Isso aproxima o trabalho da perspectiva foucaultiana que entende gênero como atravessado por relações de saber-poder e que diz dos processos de subjetivação como processos educativos. A metodologia se organizou em grupos focais e nas observações nas páginas do Facebook e do Instagram, para trazer para discussão falas e análises a partir do que foi construído por esses procedimentos metodológicos. Como resultado principal, afirma-se que os dispositivos vão atuando sobre elas, ao mesmo tempo que apresentam linhas de visibilidade, de força e de subjetivação.

Palavras-chave: gênero; feminilidade; juventudes; imagens de si; educação.

\section{Abstract}

The article is the result of a research in the field of Education, carried out with seven young women, students from a public school, interested in the relationship between the selfies images - which are published on social networks. The focus of analysis is on the devices of femininity and youth that are triggered and put into circulation for the construction of images of themselves as young women. This brings the work closer to the Foucauldian perspective that understands gender as crossed by knowledge-power relations and that says about the processes of subjectivation as educational processes. The Methodology was organized in focus groups and in the observations on the Facebook and Instagram pages, to bring up discussions and speeches based on what was built by these methodological procedures. As a main result, it is stated that the devices are acting on them, at the same time that they present lines of visibility, strength and subjectivity.

Keywords: gender; femininity; youth; images of the self; education.

Recebido em: 31/07/2020 - Aprovado em: 21/05/2021

http://dx.doi.org/10.5335/rep.v28i1.11518

Doutora em Educação pela UFJF. Mestra em Educação pela UFJF. Professora e Coordenadora da Rede Municipal de Educação de Juiz de Fora, pesquisadora do Grupo de Estudos e Pesquisas em Gênero, Sexualidade, Educação e Diversidade (GESED/UFJF). Orcid: https://orcid.org/0000-0003-2406-0027.E-mail: Natha_30@hotmail.com

** Professor associado da Faculdade de Educação da UFJF, professor permanente no PPGE/UFJF, coordenador do Grupo de Estudos e Pesquisas em Gênero, Sexualidade, Educação e Diversidade (GESED/UFJF). Pós-doutorado em Educação e Cultura Visual pela Universidade de Barcelona/Espanha. Doutor em Educação pela Unicamp. Mestre em Educação pela UFJF. Orcid: https://orcid.org/0000-0002-5681-0753. E-mail: aferrari13@globo.com 


\section{Resumen}

El artículo es el resultado de una investigación en el campo de la Educación, realizada con siete mujeres jóvenes, estudiantes de una escuela pública, interesadas en la relación entre las imágenes de selfies, que se publican en las redes sociales. El foco del análisis está en los dispositivos de feminidad y juventud que se activan y ponen en circulación para la construcción de imágenes de sí mismas como mujeres jóvenes. Esto acerca el trabajo a la perspectiva foucaultiana que entiende el género como atravesado por las relaciones conocimiento-poder y que dice de los procesos de subjetivación como procesos educativos. La Metodología se organizó en grupos focales y en las observaciones en las páginas de Facebook e Instagram, para traer discusiones y discursos basados en lo construido por estos procedimientos metodológicos. Como resultado principal, se afirma que los dispositivos están actuando sobre ellos, al mismo tiempo que presentan líneas de visibilidad, fuerza y subjetividad.

Palabras clave: género; feminidad; juventud; imágenes de si; educación.

\section{Introdução}

Os conceitos de "feminilidade" e "juventudes" que compõem o título deste artigo nos colocam diante da necessidade de esclarecer os seus entendimentos e usos. Dois conceitos que nos remetem, imediatamente, aos atravessamentos de gênero e faixa etária, na impossibilidade de falar do feminino como algo homogêneo, natural ou essência. Nesse sentido, nos aproximamos da perspectiva feminista que construiu uma crítica "ramificada e sistemática", como classifica Nancy Fraser (2019, p. 27), ao revisar as ondas do movimento feminista para afirmar que os ideais feministas de igualdade de gênero demonstram o caráter paradoxal da luta das mulheres. Por um lado, eles representam uma conquista que, hoje em dia, "são populares e fazem parte do imaginário social" (FRASER, 2019, p. 26). Por outro lado, esses mesmos ideais de igualdade necessitam ser colocados em prática cotidianamente. Com isso, Fraser (2019) está afirmando o sentido de construção das relações de gênero e a necessidade constante de luta, de maneira que estamos assumindo os conceitos de feminilidade e juventude como resultado dessas negociações e confrontos permanentes entre sujeitos, saberes e discursos atravessados por relações de poder, que se renovam constantemente. Corroborando com esses entendimentos, Michel Foucault (1988) e Joan Scott (2019) defendem que "as palavras, assim como as ideias e as coisas que elas significam, têm uma história" (SCOTT, 2019, p. 49), de tal forma que tomar como foco de análise as construções do gênero feminino e das juventudes através das imagens que as mulheres produzem de si significa colocar em investigação as descontinuidades históricas dessa ação de falar e produzir imagens de si como efeito das relações de gênero e seus processos educativos.

Isso nos obriga a ficarmos atentos para as forças atuais que agem nessas construções para problematizarmos as questões da atualidade na constituição de mu- 
lheres e suas feminilidades como resultado de processos educativos de constituição de si. Mulher e menina constituem o que vem a ser o feminino como construto performativo (BUTLER, 2001, 2003). Trazer Judith Butler para essa discussão é uma forma de tensionar o conceito de gênero como aquele que é produzido por uma sequência de atos. Seguindo as provocações de Judith Butler (2001, 2003), queremos tomar feminino para pensar o sujeito em processos constantes de produção nas relações entre os indivíduos e os saberes. A autora tensiona o feminismo, argumentando que as teóricas feministas assumiram a existência de um sujeito feminino - mulher - quase como uma essência. Para ela, a categoria mulher diz de um sujeito em processo, que é resultado dos discursos e dos atos que executa.

É necessário deixar claro, neste momento, que o nosso esforço de investigação e de análise é por essa constituição dos sujeitos nos seus processos performativos/ educativos, o que nos serve para ampliar o sentido de educação que estamos colocando em circulação como aquele que não diz somente do que acontece nas escolas e nas relações entre professora/professor e aluna/aluno, mas que envolve as relações entre sujeitos nos mais variados espaços sociais que educam, locais em que aprendemos e ensinamos como ser mulheres e homens jovens. Dito isso, é importante dizer, ainda, que este artigo tem vínculos com uma pesquisa mais abrangente, na área da Educação, especificamente no campo das relações de gênero, sexualidade e educação, realizada entre 2016 e 2019, com um grupo de sete mulheres jovens, alunas de uma mesma escola, que aceitaram o convite de contar sobre suas relações com as imagens que constroem de si e publicam nas redes sociais. São elas: Carla, Aurélia, Amélia, Laura, Vânia, Kátia, Diana ${ }^{1}$.

Além do gênero e da juventude, outro fator as une: são sete mulheres jovens, alunas e ex-alunas de uma mesma escola. Portanto, a pesquisa teve como locus de investigação as redes sociais - Facebook e Instagram - espaços virtuais em que cada uma das jovens vai se constituindo. Mas a escola também está presente. É onde elas se encontravam cotidianamente, para conversar, combinar as postagens das fotos que vão para as redes, assim como é o local em que comentavam, brigavam, de maneira que a escola e as redes sociais se integravam na constituição dessas mulheres jovens. A escola em que as jovens estudam localiza-se em um bairro na periferia da cidade. Trata-se de uma pequena escola municipal, com, aproximadamente, 270 alunas e alunos, 38 profissionais entre professoras, professores, equipe diretiva e funcionárias (números de dezembro de 2018). Nesse espaço, convivem desde crianças de 04 anos na Educação Infantil, até jovens entre 14 - 16 anos no último ano do ensino fundamental. 
Metodologicamente, a pesquisa foi realizada através da observação nas páginas construídas e públicas das participantes, além da organização de nove encontros de grupos focais (entre agosto de 2017 e outubro de 2018) em que discutimos algumas temáticas, tais como a construção de um autorretrato, as discussões em torno da rede de sociabilidade na definição das imagens a serem publicadas, dentre outras. Para além das imagens que produzem de si, também provocamos as narrativas de si nesses grupos focais. As narrativas de si são aqui entendidas como as maneiras pelas quais, nós, sujeitos de nossas histórias, nos utilizamos da ética e do cuidado consigo próprios para individualizar o que vivemos. Michel Foucault (2018, p. 141) problematiza a escrita de si como uma possibilidade de exercício pessoal:

A escrita como exercício pessoal praticado por si e para si é uma arte da verdade contrastiva; ou, mais precisamente, uma maneira reflectida de combinar a autoridade tradicional da coisa já dita com a singularidade da verdade que nela se afirma e a particularidade das circunstâncias que determinam seu uso.

Narrar-se, ter cuidado consigo mesma/o, dominar a arte da existência pode, em primeira mão, sugerir o afastamento dos convívios e voltar-se para si, entretanto, não é o que ocorre. Paradoxalmente, quanto mais trocas cada uma/um de nós é capaz de fazer com as/os outras/os, mais exercitamos o cuidado conosco mesmas/ os. Cuidar de nós mesmas/os em um ambiente social nos leva a escolhas que sejam mais próximas às nossas aspirações éticas, estéticas, aos nossos anseios, permitindo o acolhimento e o conhecimento que temos. Assim vamos nos subjetivando, seguindo e/ou questionando regras, construindo conhecimentos sobre si. Seguindo essa linha de análise, as jovens eram provocadas a se pensar, a colocar sob investigação seus modos de constituição.

De imediato, uma preocupação tomou forma: como chamar e nos referir às pessoas que fazem esta pesquisa? Acreditávamos que não podíamos nos referir a elas a partir dos nossos enquadramentos, mas que seria importante saber como se viam, se chamavam e se enquadravam nos seus atravessamentos. Não nos agradava denominá-las como meninas, tampouco como adolescentes, em função do viés ideológico, carregado de sentidos médicos, psicologizantes e preconceituosos que esses termos trazem. Colocada essa preocupação para as sete participantes da pesquisa, Vânia elabora uma resposta que, rapidamente, foi acolhida pelas demais e que, portanto, justifica nossa escolha pelo termo "mulher jovem" para nos referirmos a elas ao longo da escrita. 
Penso que sou uma mulher, acho que todas nós também somos porque a maioria aqui já namora e toma as suas próprias decisões. Assim, quero dizer que sou mulher, mas sou jovem também (Vânia).

O critério de Vânia para sua definição enquanto mulher liga-se ao fato de já ter uma vida afetiva concretizada por um relacionamento e por tomar "suas próprias decisões". Mas ela só se define como "mulher" no coletivo, na medida em que identifica que as outras também vivem algo semelhante, o que permite que fale por todas: "acho que todas nós também somos", de forma que a categoria "mulher" parece ser algo que se constrói na relação entre os gêneros, mas também no interior do gênero feminino. No entanto, se filiar a um gênero não basta, há necessidade de um atravessamento etário, visto que dizer que "é mulher" está associado à ideia de fase da vida, rompendo com períodos anteriores como criança e menina (ligados à infância e à adolescência, respectivamente) e anunciando uma etapa mais adulta. Daí a necessidade de Vânia acionar, conjuntamente, um discurso de juventude: "quero dizer que sou mulher, mas sou jovem também", estabelecendo, para si e para as outras, a categoria "mulher jovem" que, consequentemente, difere das mulheres adultas. Esses atravessamentos são constituídos e divulgados em diferentes modos de circulação do conhecimento, chegando até essas participantes, que tomam para si essa necessidade de se enquadrar em um gênero e faixa etária, dois organizadores sociais eficientes. Diante das afirmativas e concordâncias de que se consideram mulheres e jovens, a pesquisa que este artigo apresenta, foi feita com mulheres jovens entre 13 e 18 anos $^{2}$, que utilizam cotidianamente as redes sociais para dizer de si e para construir imagens de si, demonstrando que esse é um espaço educativo importante para a construção do feminino e das juventudes, nas suas continuidades e descontinuidades.

Queremos demonstrar que a sujeição que a imagem de si possibilita acontecer ativa e é ativada por dispositivos de feminilidades que atuam nas publicações de cada uma delas. Michel Foucault (1988), no exercício de pensar a sexualidade como um dispositivo, nos coloca diante da "unidade do dispositivo" como uma forma de controle que, historicamente, perpassou as monarquias, as formas da lei, avançando para o poder e os "dispositivos de aliança" que, por meio de discursos e domínios, principalmente no que se referia à sexualidade, estrategicamente, nos conduziam a uma ou outra forma de viver. Embora o filósofo não tenha falado especificamente dos dispositivos de feminilidades, este trabalho lança o olhar para esses mecanismos de construção e reconstrução de si, que encontram suporte no dito e no não-dito dos discursos, em imagens, na mídia, nos aparatos tecnológicos, 
entre outros, para discutir as maneiras pelas quais as mulheres são mais ou menos afetadas por esses construtos sociais. Estamos considerando que os dispositivos de feminilidades são mecanismos pedagógicos - pois ensinam e educam -, que podem ser imagéticos, textuais, comportamentais, discursivos, entre outros que atuam na maneira como as mulheres aprendem a ser mulheres. Em cenas sociais, na mídia, nas roupas, maquiagem, cabelo, gestos, palavras, aceitações, recusas e pertencimentos, cada uma delas vai sendo capturada por representações do feminino que são aprendidas.

Essa forma de ver e de ser vista na internet é bastante habitual entre muitas jovens em período de escolarização, fazendo com que as escolas estejam implicadas na produção de imagem (FERRARI, 2013). Viemos de um passado em que nos catálogos de venda de pneus até na publicidade de divulgação de imagens turísticas do Brasil no exterior, corpos femininos eram usados para atrair, vender, agradar, o que nos permite pensar que há uma historicidade nesses processos de ver, de ser vista e de produzir imagens de si. Essas imagens que existiam muito antes da internet já divulgavam mulheres em poses muito próximas às que encontramos nas páginas das jovens, provocando-nos a pensar que elas vão educando o olhar e o corpo ao longo dos tempos e ensinando a ser mulher, num investimento do que é ser feminino. Como desconstruir essa história de governo, exploração e abuso dos corpos femininos é uma tarefa que ainda não terminamos de fazer, podemos pensar que essas poses estão internalizadas na memória e nas práticas que unem modos de pensar e agir no processo de educação dos sujeitos. As imagens que compõem as páginas dessas mulheres jovens nas redes sociais integram um conjunto de mecanismos de governo da conduta dos indivíduos nos nossos dias, aos moldes do que Michel Foucault (1999) chama de governo de si e dos outros. Não é irrelevante dizer que existe um recorte de gênero que aponta a forma de posar, de se mostrar e de aparecer para uma foto, sendo mulher. Para Guacira Lopes Louro (2017, p. 116), as mulheres, "possivelmente mais do que homens, têm sido educadas para viver na expectativa de serem julgadas. Parece que faz parte das pedagogias da feminilidade o receio de não corresponder ao que, supostamente, delas é esperado".

Essas mulheres jovens não representam a verdade do que é ser jovem hoje, o que não significa dizer que estamos trabalhando com uma ideia de que haja uma verdade sobre o que é ser jovem. Elas são jovens que, junto a tantas outras, dão forma e dizem de uma realidade situada, instável e provisória. Metodologicamente, temos caminhado com esse sentido, ou seja, reconhecendo a instabilidade que existe na constituição dessas mulheres em suas performances de gênero feminino e 
dentro do corte geracional que as coloca como jovens. Assim como outras categorias etárias, a juventude e, consequentemente, as/os jovens fazem parte dessas disputas teóricas que tendem a maneiras distintas de entender essas pessoas. Nesse sentido, nos interessa problematizar as jovens e as juventudes como construtos sociais produzidos e que, no decorrer da história, vão mudando, transformando-se. Isso porque:

[...] cada sociedade estabelece, por meio de suas práticas, o que é ser jovem. Isso se dá em um processo que é histórico e se modifica ao longo dos tempos. A categoria juventude deve ser entendida em seu dinamismo fluidez, instabilidade e provisoriedade. Os modos de ser jovem não são fixos, nem permanentes (SALES, 2018a, p. 85).

Nessa provisoriedade e instabilidade que as jovens encontram como condição para viver suas vidas, a dimensão cultural é potente para a produção das suas juventudes. Essa dimensão cultural, nos dias em que vivemos, passa, inevitavelmente, pelas vivências digitais, proporcionadas pela internet. Jovens que estão se constituindo em diferentes espaços - físicos ou virtuais - e que nos provocam a pensar os diferentes discursos que educam essas mulheres jovens. Estar na internet produzindo a si mesmas através das imagens diz de um processo maior que atinge e tem efeitos em outras mulheres jovens e não somente entre as participantes da pesquisa.

\section{Dispositivo de feminilidade}

Os dispositivos atuam na nossa vida nos organizando e nos constituindo. Essa é uma afirmação seguindo as trilhas das investigações foucaultianas que nos permitem dizer que os dispositivos estão ligados às relações de poder, aos saberes e às "verdades" dos sujeitos. Michel Foucault (2018) amplia o entendimento de dispositivo como aquele composto por discursos, leis, construções arquitetônicas, práticas médicas e jurídicas, postulados científicos, enfim, uma rede que se constitui entre esses elementos. São essas redes que podemos tecer entre esses elementos que nos interessa, quando pensamos nas feminilidades como dispositivo. Ao entendermos isso, torna-se possível problematizar que os discursos e também outras formas não discursivas de organização da sociedade contribuem para a construção desse mecanismo. Entender que as feminilidades estão em permanente construção, como estamos defendendo, significa tomar essa rede como objeto de investigação nos seus processos de constituição dessas mulheres jovens e seus desafios e potencialidades na atualidade. 
$\mathrm{Na}$ atualidade de uma sociedade imagética, as imagens selfies são, ao mesmo tempo, partes e disparadoras dos dispositivos da feminilidade, das juventudes, das subjetividades, uma vez que colocam em funcionamento o processo de produção, discussão, divulgação, aceitação e/ou rejeição que dele advém. As participantes da pesquisa sentem prazer em ter um aparelho celular nas mãos e em poder produzir imagens de si. Prazer que se traduz no poder de ter o controle sobre a produção de si, de apagar as fotografias que julgam como inadequadas para uma construção favorável e valorizada de si. Prazer que dialoga com poder o tempo todo, desde o poder em disputar o melhor celular e, portanto, mais potente para a valorização das fotografias, até o poder em conseguir realizar uma imagem que, primeiramente, passe pela avaliação, pela aprovação das outras amigas para se concretizar em números de curtidas e comentários nas redes sociais. Esses prazeres, os sentimentos de valorização e de participação de um contexto juvenil em rede, assim como as trocas e construção de laços entre mulheres vão estabelecendo e fortalecendo o dispositivo da feminilidade, que inclui, em sua composição, formas discursivas e não discursivas, além de aliar instância de saber e de poder que atuam sobre as pessoas, constituindo-as. As redes sociais são dispositivos na vida dessas mulheres jovens.

Para mim, selfie é aquela foto que você mesma tira e decide se você gosta ou não, mas a selfie perfeita é aquela que você acha que ficou bonita e pergunta para as amigas se está boa e elas falam que está. Para as meninas a selfie tem que estar perfeita (Amélia).

Num lugar com árvore, o brilho certo, um carão bem top! Fazer montagem, colocar emojis ${ }^{3}$. Num lugar legal, paisagem legal, igual às fotos da Maria Venture 4 (Vânia).

Selfie para mim é uma foto top, uma foto tirada por mim mesma que representa a pessoa, mostra se ela gosta de viajar, o que gosta de comer, que tipo de lugares que ela gosta de frequentar (Kátia).

Eu acho a selfie importante para mostrar como a pessoa parece ser, o jeito dela, o que ela gosta de fazer, além de ser importante ficar bonita e mostrar para as pessoas (Carla).

Selfie é uma coisa que gosto muito, é como a gente guarda lembranças. Tem que ter o local perfeito, luz ideal. Pessoas que são boas em selfies são o Victor Hugo, Maria Venture e Ana Gabriela que são todos Youtubers (Laura).

Selfie para mim é importante e eu gosto muito de tirar. Ficar bonita, com um bom fundo para ficar boa. Eu gosto de me inspirar na Mari Maria ${ }^{5}$ (Diana).

As selfies compõem as páginas dessas mulheres jovens. Ao pesquisarmos nas páginas pessoais das participantes da pesquisa, constatamos que a fotografia de apresentação, com suas poses, com os acessórios que escolheram, com as pessoas que compõem a imagem, passam informações que querem construir de si nesse 
momento, considerando que essas fotografias podem mudar e mudam na medida em que iniciam ou encerram determinados momentos da vida pessoal. Quando aparecem de corpo inteiro, as roupas são justas, com decotes, saias mostrando as pernas, num ar de sensualidade que marca o corpo feminino. Quando aparecem em fotografias de rosto, o mesmo ar de sensualidade é marcado pelo olhar, estando sempre muito bem maquiadas, demonstrando um investimento nas fotografias. Os acessórios que utilizam também contribuem para a construção do feminino ou do que convencionamos como próprio do gênero feminino. Assim, as fotografias utilizam espelhos, coroas e tiaras em tons de dourado, símbolos de coração, imagens em que aparecem abraçadas com namorados, fotos tiradas por ocasião da suas festas de 15 anos, definindo vínculos com a juventude a partir desse rito de passagem.

Essas são interpretações possíveis daquela/e que olha e que vai preenchendo o espaço do vazio entre a foto e nossos olhares, utilizando, para esse preenchimento, os valores, os saberes e os discursos que os corpos, os gêneros, os símbolos e as poses vão acionando naquela/e que olha e que é chamada/o a ler as imagens através desse diálogo entre que sentidos queriam passar e o que somos capazes de elaborar. Para além dos grupos focais, ouvíamos, em outras ocasiões de sociabilidade e conversas informais, essas jovens mulheres fazendo referência ao que fora postado em redes sociais. Assim, podíamos perceber que essa circulação e construção de si nesse ambiente eram algo do cotidiano e de importância para as relações de trocas entre elas. Inclusive, durante a pesquisa, as jovens falaram sobre os status ${ }^{6}$ do WhatsApp como um espaço de "mandar recado" para as "amigas e inimigas". Mandar recado parece ser uma forma de controlar as outras mulheres jovens e a si mesmas na constituição desse coletivo de feminilidade no estabelecimento de regras do que é permitido e proibido. Numa conversa sobre esse controle pelas imagens, Kátia afirma: "Agora 'tô' namorando e as coisas mudam um pouco. Não posto tantas fotos e nem sempre vou ficar dançando aqui na escola". Concordando com essa mudança de comportamento na internet, Amélia, reforça: "Quando a gente namora, a gente posta muito menos". Esse espaço captura a atenção e faz a vigilância ser uma constante entre as jovens. Manter-se ativa nas redes sociais significa ter uma boa foto, com uma luz adequada, saber o horário adequado para inseri-la, ter muitos contatos.

Para isso, pode-se começar a pensar o gênero baseado numa visão teórica foucaultiana, que vê a sexualidade como uma "tecnologia sexual"; dessa forma, seria possível propor que também o gênero, como representação e como autorrepresentação, fosse produto de diferentes tecnologias sociais, como cinema, por exemplo, e de discursos, epistemologias e práticas críticas institucionalizadas, bem como das práticas da vida cotidiana (LAURETIS, 2019, p. 123). 
Ampliando a citação de Teresa de Lauretis (2019), no seu diálogo com a perspectiva foucaultiana, tomamos a construção do gênero, especificamente o lugar de mulher jovem desse grupo pesquisado, como construído significativamente nas redes sociais. Coletivamente, através das redes sociais, do que produzem de si e que confirmam nas publicações das demais participantes, vão construindo a si mesmas como mulheres jovens, pertencentes ao que é a representação desse gênero e dessa faixa etária. Carla, ao dizer que " $a$ reação das pessoas às minhas fotos é importante porque me sinto especial", parece nos apontar para a relevância que a reação de uma outra/um outro possui nessa feminilidade em construção.

Emprestar energia a uma imagem diz de um esforço que existe em se ver representada, em uma rede de significações que criam personagens mais ou menos populares nas redes sociais. Nessa busca pela popularidade e aceitação das demais, Carla traz à tona um certo uso dos mecanismos de produção dessa popularidade: "Eu até me importo com as curtidas, mas, se é pra ter curtidas, é só você buscar um aplicativo no Google que é pra aumentar seus likes. Você coloca o tanto de curtidas que quer e o aplicativo vai lá e coloca". Questionada sobre as razões dessa estratégia, ela completa: "É porque as pessoas vão ver sua rede cheia de curtidas, vão curtir também. Aí você passa a ser alguém como muitos seguidores". Sentir-se especial nas redes sociais tem a ver com ser gostada/o, possuir uma imagem que seja simpática às/aos demais, significa ser aprovada/o. E, para serem aprovadas, no caso das jovens participantes, elas vão balizando suas condutas em uma ou outra maneira que lhes seja satisfatória.

Temos os nossos grupos de WhatsApp que mostramos nossas roupas e maquiagens antes de sair, ou até mesmo antes de postar a foto na internet, porque as amigas do grupo são aquelas que são mais, que são próximas, então a gente vai lá e pergunta. Manda a foto e pergunta. Dependendo do que ela responder aí a gente pode até trocar a roupa, mudar tudo mesmo. (Diana).

Esperando a aprovação das outras meninas e, posteriormente, das suas seguidoras e seguidores, elas nos convidam a pensar que o feminino não é algo que já está pronto, mas, ao contrário disso, é algo que diz de um investimento, que tem uma temporalidade. Como ressalta Butler (2019), gênero não é uma propriedade do corpo e, tampouco, algo que existe a priori nos sujeitos. A ação das mulheres jovens com a produção e a divulgação de imagens de si nos convida a problematizar a construção do feminino como o conjunto de efeitos produzidos nesses corpos (não por acaso, as poses se repetem, com pouca variação entre elas), nos comportamentos que valorizam e desvalorizam, que reproduzem ou negam e nas relações sociais 
que vão construindo em torno dessa amizade como desdobramento dessa complexa tecnologia política que é o gênero. "Neste sentido, saber o significado de alguma coisa é saber como e por que ela importa, sendo que "importar" significa ao mesmo tempo "materializar" e "significar" (BUTLER, 2019, p. 63-64).

Nesse jogo entre o que importa e o que é valorizado, Carla nos provoca a pensar sobre a imagem nas redes sociais ao ter em sua capa, no Facebook, uma foto de seu aniversário de 15 anos. Entre tantas coisas que se pode dizer sobre ela mesma, Carla escolheu a imagem em que está representada por elementos que a colocam em um padrão aceitável para si e para as outras e outros, uma mulher feminina. Entende que usar maquiagem, acessórios, trajar um vestido e salto alto a coloca em um lugar que talvez seja o aceitável, desejável. O dispositivo de feminilidade acionado, no caso de Carla, em sua festa de 15 anos, teve a ver com a padronização dessa feminilidade que conhecemos a partir desse rito de passagem que comumente é associado ao feminino. Assim como Aurélia, que também pediu, como presente de aniversário de 15 anos, um dia de princesa como o que viveu Carla. As fotos desse "momento de princesa", nos dois casos, foram muito divulgadas nas redes sociais das duas jovens, conquistando muitas curtidas e comentários, o que foi motivo de prazer e poder, criando uma rede de amizades que se ampliou nesse momento na escola, fornecendo um outro lugar na escola e entre as jovens.

Shirley Sales (2018b, p. 117) afirma que as condutas juvenis "passam pelo julgamento das/os outras/os internautas que avaliam constantemente a conduta dos pares, em um ciclo permanente de práticas de governo de si e das/os outras/os". A internet é um território de existência e as fotos selfies possibilitam que as jovens façam contato, interajam, se expressem e compartilhem o conhecimento acerca de si e de como é ser mulher. Ao experimentarem o poder que a imagem representa, estão construindo e compartilhando saberes sobre beleza, sedução, comportamento, roupas, acessórios, enfim, saberes que dialogam com outros espaços de aprendizagem do que é ser mulher jovem, como cinema, televisão, revistas, publicidade.

Carla está atenta ao que se passa em suas redes, o que pode ser observado por meio de memes $^{7}$ que posta em sua timeline. Essa constatação de que há um código de aceitação que também circula na internet foi percebido por Carla. Ela, entendendo que há uma certa hegemonia nas imagens publicadas, nas mensagens postadas, utiliza esse conhecimento como balizador de sua figura on-line. Esse tipo de aprendizagem que as redes sociais ensinaram à Carla possibilitou que ela se aventurasse em testar sua aceitação ou popularidade por meio de memes que necessitam de respostas sobre ela. $\mathrm{O}$ código da popularidade também passa pela 
aceitação do que é postado, mesmo que não seja imagem da própria pessoa. Ser popular também passa por postar bons memes, estar atenta às novidades musicais e das celebridades da TV e da internet.

Eu gosto muito do $\mathrm{BTS}^{8}$ e na escola não é todo mundo que gosta. Eu sigo a página deles e tudo que existe para saber mais sobre eles. Às vezes quem gosta das coisas que eu posto nem é gente daqui, porque aqui na minha sala o povo gosta mais de funk (Carla).

Carla diz que o grupo musical do qual é fã não é o mesmo da maioria de suas/ seus companheiras/os da escola, entretanto, na internet, esse tipo de postagem confere a ela popularidade e aceitação. Ser popular e aceita tem sentido de pertencimento e permanência na internet, nas redes sociais e isso modifica as formas como cada uma das jovens se movimenta no espaço virtual, de maneira que elas se tornam espelho daquilo que admiram.

Sustentar uma imagem na internet significa lidar com a vigilância, que, de acordo com Foucault (2009), tem ligação com a vontade de saber: é uma forma de dispositivo muito utilizada pela sociedade. A vigilância em torno da sexualidade funciona como um dispositivo, ou seja, diz do "prazer da verdade do prazer, prazer de sabê-la, exibi-la, descobri-la, de fascinar-se ao vê-la, secretamente, desalojá-la por meio de astúcia; prazer específico do discurso verdadeiro sobre o prazer" (FOUCAULT, 2009, p. 81). O dispositivo da sexualidade auxilia no controle dos corpos e na manutenção de uma ordem sobre o corpo, o desejo e as vontades. As falas das participantes apontam que o desejo e a vontade de postar passam pelo julgamento da outra em torno da "foto perfeita". "Às vezes eu acho que a selfie ficou perfeita, ficou bonita, ai eu vou perguntar para as minhas amigas se 'tá boa mesmo', se elas falarem que está boa, eu vejo que a foto está mesmo perfeita" (Laura). Os critérios de beleza são construídos e compartilhados nesse grupo, pela aprovação ou não das fotos, de modo que vão ensinando umas às outras o que é ser uma mulher jovem bonita. Sobre essa rede estabelecida entre elas, Vânia conclui: "Eu acho importante a opinião das outras pessoas sobre as minhas fotos porque às vezes elas veem coisas que talvez eu não veja".

Podemos sugerir que as redes sociais são locais de visibilidade e também de discurso no nosso cotidiano. Fazer-se mulher passa, de maneira mais ou menos intensa, por se produzir como tal, espelhar-se como tal, entender-se como tal, discursivamente, entendendo-se como tal. Com isso, queremos dizer que não há uma identidade ou subjetividade fixa nessa construção de ser mulher e ser jovem. Não somente Carla, mas também as outras mulheres incessantemente estão construindo-se e descontruindo-se de acordo com os discursos que lhes afetam. Um exemplo dessa afetação 
foi a transformação de Kátia ao entrar em um relacionamento sério, tomando como verdade o discurso da fidelidade e do amor eterno, referendado também por Diana, que, desde o início de nossa pesquisa, já possuía um anel de compromisso no dedo anelar direito. À medida que assumiram o "relacionamento sério", rapidamente, alteraram o status nas suas páginas para "namorando", assim como modificaram seus comportamentos diminuindo as postagens, dando preferência às imagens em que estavam com os namorados. As subjetivações pelas quais passou Laura, ao mudar de escola e ingressar no Ensino Médio em uma escola maior, também foram para as suas páginas, com fotos de novas amizades e espaço de circulação. As questões ligadas ao corpo gordo que antes não apareciam em suas falas e que muito nos chamavam a atenção passaram a fazer parte de um discurso mais presente:

Laura: (...) você viu que a Kátia 'tava falando que 'tá gorda?

Entrevistadora: Claro que ouvi! [risos]. Pensei em mim na hora!

Laura: Já pensou se a Kátia for gorda? Se ela for gorda, nem sei o que eu sou!

Kátia: E eu engordei mesmo, gente! Desde que comecei com o luri, eu aumentei cinco quilos.

Em nossos encontros anteriores, Laura não sinalizava nenhum incômodo ou fazia qualquer referência à obesidade. Nas redes socais também não se colocava como pessoa gorda. Isso nos faz pensar que os dispositivos de feminilidade acionados por padrões podem estar capturando Laura no entendimento de que um corpo bonito é um corpo magro. Na sua fala encontramos a sedução que um corpo magro desperta em nossa sociedade. Ela se utiliza da comparação ao corpo magro de Kátia como referência para o corpo obeso dela. Esse jogo de sedução que nos enquadra e nos diminui, embora sejamos grandes em tamanho, também captura Kátia, que não deseja ficar maior do que já está, mesmo sendo esse ganho de peso resultado da calmaria de um namoro que vem acompanhado de lanches e mais comida junto ao namorado. Subjetivamo-nos de maneira mais ou menos intensa tendo os dispositivos de feminilidade como componentes nesta tarefa que é tornar-se mulher jovem.

\section{Continuidade e descontinuidade no dispositivo da feminilidade}

Continuidade e descontinuidade foram aspectos que marcaram as redes estabelecidas entre as jovens participantes, demonstrando que o gênero não é uma construção estável, "mas uma identidade tenuamente constituída no tempo - identidade instituída por meio de uma repetição estilizada de certos atos" (BUTLER, 2019, p. 213-214, grifos da autora). Ao mesmo tempo em que determinadas ações 
eram contínuas entre elas, como as poses que se repetiam nas selfies, outras marcavam uma descontinuidade como, por exemplo, a relação com a sexualidade, rompendo com a associação gênero/heterossexualidade. Mas trabalhar com continuidade e descontinuidade no dispositivo da feminilidade nos remete ao arcabouço foucaultiano e à sua influência nos estudos de gênero e sexualidade, principalmente no que se referem à perspectiva histórica da construção desses conceitos e, consequentemente, ao rompimento com a ideia de essência.

A descontinuidade aparece no trabalho de Michel Foucault (1986, 1988, 2007), sendo considerada um dos eixos fundamentais quando se dedica à análise histórica. Para ele, a história é descontinuidade. Nesse sentido, a descontinuidade passa a ser a estratégia utilizada para descontruir os essencialismos com que lidamos no nosso tempo, ao mesmo tempo que serve para ironizar a ideia de origem e, por último, para desestabilizar os lugares de verdade e suas relações de saber-poder no discurso do conhecimento, visto que a história é marcada pelas rupturas e descontinuidades. Na sua análise histórica, Michel Foucault criticava a história por sua insistência pela continuidade, pela crença em uma origem essencial que subsiste ao tempo e que comanda os destinos dos sujeitos. Um pensamento que contribuiu para a formulação das teorias de gênero, retirando-o de um modelo essencial e aproximando suas análises à necessidade de uma postura que considere a sua historicidade como descontinuidade, sobretudo em relação a uma certa temporalidade social.

Se os gêneros são instituídos por atos descontínuos, essa ilusão de essência não é nada mais além de uma ilusão, uma identidade construída, uma performance em que as pessoas comuns, incluindo os próprios atores sociais que as executam, passam a acreditar e performar um modelo de crenças. Se a base da identidade de gênero é a contínua repetição estilizada de certos atos, e não uma identidade aparentemente harmoniosa, as possibilidades de transformação dos gêneros estão na relação arbitrária desses atos, na possibilidade de um padrão diferente de repetição, na quebra ou subversão da repetição do estilo mobilizado (BUTLER, 2019, p. 214).

A citação de Butler (2019) reforça a ideia de gênero como "instituído por atos descontínuos", ao mesmo tempo em que afirma a necessidade de uma certa continuidade para a construção da "identidade de gênero". Podemos pensar que a descontinuidade e a continuidade marcam a construção dos gêneros e das identidades de gênero. As participantes performam e colocam em circulação um "modelo de crenças" em torno do que é ser mulher jovem, sobretudo porque falam de si em meio à metodologia do grupo focal, em que a fala de uma se encontra com as demais.

Num dos encontros que tivemos, Amélia "revela-se" grávida, esperando sua filha, Emília, para janeiro de 2019. Falar de si agora é falar do processo de ser mãe: 
Amélia: 'Tô ansiosa, 'tô com medo, 'tô com tudo. Mas também é uma sensação muito boa, às vezes eu me estresso muuuitooo (sic), mas agora consigo me controlar mais um pouco; é porque tem muito hormônio.

Entrevistadora: Daqui uns dias a Emília vai estar aqui com a gente [na escola] correndo com quatro anos. Nem acredito, parece que sou avó, porque te vi aqui, Amélia, com quatro anos.

Amélia: Tem horas que nem eu acredito.

A gravidez de Amélia a desloca dentro da própria juventude e confere a ela um lugar outro que não seja somente de jovem, estudante, compromissada, periférica, negra. Essa descontinuidade é marcada pelo tempo, ou seja, só é descontinuidade porque, social e discursivamente, não se espera gravidez na adolescência, construída como um problema. Ao mesmo tempo que marca sua descontinuidade no grupo, visto que se trata de um grupo de mulheres jovens, Amélia também anuncia um futuro, reforça um desejo nas demais participantes, inclusive na entrevistadora, que, rapidamente, estabelece uma identidade de se "sentir avó", marcando uma continuidade com Amélia a partir da escola, do seu vínculo com entre educação e família. Após o nascimento da criança, ela também se transforma em mãe da Emília e isso fica muito evidente nas muitas imagens da filha que divulga nas redes sociais. A sua nova identidade como mãe é construída, performativamente, nas redes sociais, junto com as imagens da filha, com roupas femininas, com acessórios femininos, enfim, como se estivesse "brincando" de boneca, possivelmente como aprendera desde muito jovem. Amélia também vem construindo a imagem de Emília na internet: divulga fotos, faz postagens, declarações e publicações sobre a filha. A criança e o discurso de maternidade conferem à Amélia uma nova subjetividade: a de mãe jovem. O discurso, além de uma prática de produção de sujeitos, é também uma prática social que controla a produção, a circulação e a apropriação dos enunciados, como explora Foucault (1986). Nas palavras do autor, discursos são:

[...] práticas que formam sistematicamente os objetos de que falam. Certamente os discursos são feitos de signos; mas o que fazem é mais que utilizar esses signos para designar coisas. É esse mais que os torna irredutíveis à língua e ao ato da fala. É esse "mais" que é preciso fazer aparecer e que é preciso descrever (FOUCAULT, 1986, p. 56).

Discursiva e performativamente, Amélia vai tornando-se mãe. A gravidez, na medida em que ocorre, também se transforma em investimento nas redes sociais. Amélia passa a postar imagens de si na transformação do corpo e, assim, vai se subjetivando como mulher jovem grávida para, depois, investir em imagens de si como mulher, negra, jovem mãe. Para isso, é fundamental imagens da filha seguida de mensagens como "Amor que não se mede", "filha", "apaixonada". A partir de 
Foucault, podemos pensar que Amélia não constrói sentidos de ser mãe de maneira livre, mas ela é subjetivada como mãe a partir de sistemas de restrição e incitação a ser mãe, como aquela que ama incondicionalmente, que está apaixonada pela filha, atos que se repetem. O saber-poder de ser mãe em sua positividade vai produzindo verdades para Amélia mãe.

A ação de postar imagens da filha nos possibilita problematizar as redes sociais em processos de subjetivação. Emília está crescendo e sendo educada por meio de imagens que são divulgadas de si mesma, ainda que não tenha consciência disso. O macacão que Amélia escolhe para vestir Emília, com a estampa do Instagram, já demonstra que a inserção nesse mundo conectado se inicia antes mesmo que a pessoa tenha escolha para dele participar. Agora Amélia também é mãe: a única mãe do grupo. Problematizando sobre gravidez e juventude, Helena Altmann (2007) destaca a questão do biopoder de Michel Foucault como mecanismo de controle e dominação dos corpos. Altmann (2007) faz uma análise em que nos coloca em contato com o senso comum para compreender que circula na sociedade a ideia de que uma jovem grávida encerra possibilidades na vida. Partindo dessa questão, problematiza a ideia de que tanto a juventude quanto a gravidez são construções sociais que sofrem mudanças ao longo da história. Não é natural e essencial que a mulher queira ser mãe. Entretanto, o que observamos com Amélia e as demais jovens é que essa condição alterou seu lugar no grupo. A mudança de Amélia dentro do grupo e também das outras jovens em relação a ela, nos faz olhar para a gravidez e a maternidade não somente como fenômenos biológicos, mas sobretudo culturais, históricas, sociais e afetivas.

Esse entendimento de que Amélia teve sua subjetividade alterada com a chegada de Emília, outra mulher que se apresenta nesta pesquisa, nos deixa perceber que esse acontecimento trouxe elementos para o discurso de Amélia, até então ausentes. Quando ela diz que "tá ansiosa, tá com medo" e as outras escutam com atenção e respeito, isso vai dando um sentido de mulher não só para Amélia, mas para todas, inclusive para as leitoras mulheres deste artigo. Os discursos de maternidade, em nossa sociedade, vão constituindo o lugar do feminino, de tal maneira que é "esperado" que mulheres tenham filhos fazendo o discurso de maternidade ser uma prática social que só existe como ato. Daí o sentimento de completude que é experimentado por aquelas (não todas) que se descobrem grávidas e o sentido de incompletude quando não se consegue engravidar. A maternidade está inscrita em um tipo de saber-poder que produz mulheres grávidas e não grávidas, que divide, inclui e exclui, que só pode ser entendido em meio a essas relações entre os gêneros e no interior do gênero feminino. 
Esse discurso circulante no grupo contribui para a construção do gênero entre mulheres que estão vivenciando a maternidade de Amélia de perto. No interior do próprio gênero, vão se entendendo como mulheres que podemos escolher entre maternar ou não. Ainda no interior do gênero, formam uma rede que vai fornecendo sentidos para a gravidez, a juventude e a escola, uma rede que acolhe e rechaça, que constrói desejo de repetição e possibilidades de outros caminhos, enfim, reforça o entendimento de gênero como resultado de atos descontínuos e das performatividades que estão presentes nesses elementos.

Amélia traz muitos sentidos para o dispositivo da feminilidade que circula no grupo e atravessa de maneira contundente a todas as jovens mulheres participantes. A história de gravidez que Amélia está construindo faz todas elas se olharem e se pensarem e, mais do que isso, a criarem expectativas em torno de projetos de casamento e filhos, sem a garantia de cumprimento, mas Amélia parece anunciar o "destino manifesto" das mulheres, como se fosse algo homogêneo. Esses projetos em torno do casamento e da maternidade estão inscritos no dispositivo da feminilidade operando em todas as participantes na forma como planejam suas histórias de vida em relação a outras mulheres, a outras histórias que conhecem, que compartilham e que passam a desejar. No entanto, o imponderável é parte desse processo, não garantindo que as histórias se repitam. O fato de não se repetir não significa que não exista, mesmo que tenha sido uma verdade momentânea, existe enquanto possibilidade, enquanto desejo socialmente valorizado, gerado por um discurso que parece verossímil para um determinado momento da vida. A gravidez de Amélia aciona, em todas as participantes do grupo, o dispositivo da feminilidade que permite a cada uma delas se olhar através de Amélia e sua gravidez, principalmente Kátia e Diana, que acolheram a gravidez de maneira mais próxima. Michel Foucault (2007, p. 16-17) reflete sobre esses processos de transformação dos sujeitos:

[...] práticas reflexivas e voluntárias pelas quais os homens não somente se fixam regras de conduta, mas procuram se transformar a si próprios, se modificar em seu ser singular e fazer de sua vida uma obra que sustente certos valores estéticos e responda a certos critérios de estilo.

E quais não foram os acontecimentos que vieram e mudaram os modos de pensar, como as novidades, como práticas históricas, irromperam a linearidade de um destino? Esses acontecimentos afetam as formas com as quais nos subjetivamos, forçando-nos a não sermos mais as mesmas ou os mesmos. Essas regras de existência que damos a nós mesmas/os vão ganhando contornos morais e éticos que fazem parte do processo de subjetivação. Foucault (1994) entende que essa ética como 
cuidado de si existe porque cada uma/um de nós reflete sobre si mesma/o de acordo com regras que vão dando contorno às existências, na medida em que o "cuidado de si atravessou verdadeiramente todo o pensamento moral" (FOUCAULT, 1994, p. 262). Essa relação existente entre moral e ética, que atravessa a constituição dos sujeitos, passa, inevitavelmente, pela presença das/os outras/os. Assim, é potente perceber que a/o outra/o é alguém que contribui para que sejamos o que somos, uma vez que desestabiliza nossas certezas. O sujeito ético entende que dar sentido à própria vida significa trabalhar sobre si mesmo e interagir com os demais; cuidar de si é uma maneira de enfrentar as opressões e de se posicionar em resistência contra os poderes políticos que ameaçam novas formas de subjetividade.

Questionar-se eticamente frente às desigualdades e aos preconceitos do mundo, não aceitar a vida em sua forma limitada e estreita, não se conformar, assim entendemos a estética da existência presente no pensamento de Michel Foucault e que nos orienta na maneira como problematizamos os posicionamentos de Aurélia, por exemplo. Ela se descobre com uma jovem mulher negra, que questiona a ausência de variedade em cosmética para o seu tipo de pele:

É difícil encontrar coisas para minha pele, por exemplo. Até o filtro solar é para pele de pessoas brancas, mas eu uso mesmo assim. Algumas pessoas pensam que, por eu ser negra, não preciso usar filtro solar, mas eu também me queimo! (Aurélia).

Cada uma dessas jovens traz as demais, as falas de cada uma delas reverberam nas outras, fazem com que se vejam e se revisitem. Elas existem como parte desta investigação, nas relações que estabelecem entre si nas suas performatividades de gênero, em que características biológicas são descartadas no entendimento de como nos tornamos mulheres, homens ou nenhum dois (BUTLER, 2018).

A feminilidade e seu dispositivo estão em atuação nessa construção e atuam principalmente no entendimento de uma "identidade primária" ou original que tende a ser entendida por uma grande maioria de pessoas como estável. Na relação entre nós, que somos iguais, vamos construindo nosso gênero. O dispositivo da feminilidade nos une e é acionado na construção do gênero e no interior do próprio gênero, é algo que nos precede e faz parte de uma norma cultural a que estamos expostas. Judith Butler (2018, p. 71) nos diz que:

O fato de que as normas agem sobre nós implica que somos suscetíveis à sua ação, vulneráveis a uma certa nomeação desde o início. $\mathrm{E}$ isso se inscreve em um nível que antecede qualquer possibilidade de volição. [...] A performatividade de gênero não caracteriza apenas o que fazemos, mas como o discurso e o poder institucional nos afetam, nos restringindo e nos movendo em relação ao que passamos a chamar de a nossa "própria" ação. 
Cada existência pode ser percebida como uma criação discursiva, uma invenção dos sujeitos na movimentada tarefa que é constituir-se. As normas vão sendo incorporadas pelo discurso, que existem antes mesmo de habitarmos este mundo, ou seja, já chegamos ao mundo organizado discursivamente. Entretanto, a arte de viver nos desafia e possibilita que alguns acontecimentos se tornem fortes 0 bastante para mudar uma trajetória, um pensamento, uma forma de ver a vida.

Essas subjetivações dão suporte aos dispositivos de feminilidade que constituem o sujeito em espaços de ação. Dispositivo de feminilidade é um conceito e investimento neste trabalho, tendo como fundamento o conceito de dispositivo de Michel Foucault (1988), que nos indica haver uma rede que interliga vários aspectos da vida social, agindo em cada um de nós, individualmente ou em conjunto, de maneira a interferir na ação dos outros sobre mim e de mim sobre mim mesmo, acionando os campos de saber, de poder e subjetividade. Fabiana de Amorim Marcello (2004), abordando a presença do dispositivo na experiência da maternidade, faz uma discussão a respeito do conceito que foi muito útil para a escrita deste trabalho. Nas palavras da autora:

Já que Foucault se refere tão explicitamente a elementos tais como discursos, organizações arquitetônicas, leis, medidas administrativas, enunciados científicos, podemos entender que as práticas discursivas e não-discursivas contribuem para a construção do dispositivo e, tendo estes presentes, é possível afirmar ainda que o conceito em questão reúne as instâncias do "poder e [do] saber numa grade específica de análise" (MARCELLO, 2004, p. 200).

A emergência do dispositivo da feminilidade pôde ser vista na relação entre as jovens mulheres e suas muitas selfies publicadas nas redes sociais. Além disso, também se apresentava como uma produção cotidiana de imagens feitas por meio de celulares como parte da realidade de cada uma delas e que faz parte das suas relações interpessoais. Apropriam-se do discurso, da imagem e da representação do poder de uma foto e assim vão construindo suas subjetividades narradas on-line. Nas narrativas de si, em que cada história é vista como uma forma de se colocar frente ao mundo com suas pressões, opressões e naturalizações, fomos buscando nossas formas de entendermos, por meio de nossas palavras, fomos construindo nossos discursos. Foucault (2007, p. 92) assim diz:

Trata-se, então, de constituir-se e reconhecer-se enquanto sujeito de suas próprias ações, não através de um sistema de signos marcando poder sobre os outros, mas através de uma relação tanto quanto possível independente do status e de suas forças exteriores, já que ela se realiza na soberania que se exerce sobre si próprio.

É o que somos capazes de construir discursivamente que vai constituindo nossa subjetividade. Foucault trabalha com o que vem à tona e, quando direcionamos 
nossos olhares para as mulheres jovens e as maneiras como constroem suas páginas, entendemos que elas estão dando vidas às suas vivências, estão construindo-se discursivamente. E isso nunca é igual, assim como as juventudes também não são. As subjetividades dessas pessoas possivelmente passam pelas imagens que também as constituem.

Por fim, queremos afirmar que, nessa problematização em torno das imagens selfies e as constituições de subjetividades em mulheres jovens, os dispositivos vão atuando sobre elas, modificando e forjando outras no seu interior. Ao mesmo tempo que os dispositivos apresentam linhas de visibilidade, de força e de subjetivação, eles também apontam descontinuidades nas fissuras e brechas possíveis, sobretudo na potência de encontros como realizamos nos grupos focais, investindo na problematização e apostando nas transformações advindas das falas de cada uma delas e nas possibilidades de colocar sob suspeita suas formas de ser, pensar e estar no mundo.

\section{Notas}

1 Os nomes das participantes são fictícios. Buscamos, assim, preservar o anonimato em torno dessas mulheres que, juntas, construíram esta pesquisa com suas falas, que aparecerão sempre em itálico para diferenciar das demais citações.

2 Essas idades se referem ao ano de 2018.

3 Emojis são figurinhas que representam expressões.

4 Maria Venture é uma youtuber e influenciadora digital com quase um milhão de seguidores.

5 Mari Maria é também uma youtuber e influenciadora digital com mais de 1.200.000 seguidores e seguidoras no Instagram e 700 mil inscritos no seu canal do YouTube.

6 Status do WhatsApp é uma ferramenta do aplicativo que permite a postagem de uma foto, frase, poesia, para ficar ativa durante 24 horas, permitindo ao usuário e a usuária saber quem visualizou a publicação. Esse recurso, oriundo do SnapChat, também está disponível no Instagram e Facebook.

7 Memes, termo oriundo do grego que significa imitação, são piadas, ou formas divertidas de falar sobre determinado assunto que se tornou muito popular na internet.

8 BTS ou Bangtan Boys é um grupo musical sul-coreano composto por homens jovens que se tornou um fenômeno mundial no ano de 2013.

\section{Referências}

ALTMANN, Helena. A sexualidade adolescente como foco de investimento político-social. Educação em Revista, n. 46, p. 287-310, 2007.

BUTLER, Judith. Corpos que pesam: sobre os limites discursivos do sexo. In: LOURO, Guacira Lopes (org.). O corpo educado: pedagogias da sexualidade. 2. ed. Belo Horizonte: Autêntica, 2001. p. 151-171.

BUTLER, Judith. Problema de gênero: feminismo e subversão da identidade. Rio de Janeiro: Civilização Brasileira, 2003. 
BUTLER, Judith. Quadros de guerra: quando a vida é passível de luto? Rio de Janeiro: Civilização Brasileira, 2018.

BUTLER, Judith. Corpos que importam: os limites discursivos do "sexo". São Paulo: n-1 edições, 2019.

FERRARI, Anderson. O que os adolescentes produzem de imagens? Cultura Visual, adolescências e educação. Revista Visualidades, Goiânia: UFG, v. 11, n. 2, p. 13-35, 2013.

FOUCAULT, Michel. A arqueologia do saber. Rio de Janeiro: Forense Universitária, 1986.

FOUCAULT, Michel. Ditos e escritos V: Ética, Sexualidade, Política. São Paulo: Forense, 1994.

FOUCAULT, Michel. História da Sexualidade I: a vontade de saber. Rio de Janeiro: Graal, 1988.

FOUCAULT, Michel. Microfísica do poder. 14. ed. Rio de Janeiro: Graal, 1999.

FOUCAULT, Michel. História da sexualidade III: o cuidado de si. 9 ed. São Paulo: Graal, 2007.

FOUCAULT, Michel. Ditos e Escritos III - Estética: Literatura e Pintura, Música e Cinema. 2. ed. Rio de Janeiro: Forense Universitária, 2009.

FOUCAULT, Michel. O que é um autor? 10. ed. Lisboa: Nova Veja Passagens, 2018.

FRASER, Nancy. Feminismo, capitalismo e a astúcia da história. In: HOLLANDA, Heloisa Buarque de. Pensamento feminista: conceitos fundamentais. Rio de Janeiro: Bazar do Tempo, 2019. p. 25-48.

LAURETIS, Teresa. A tecnologia de gênero. In: HOLLANDA, Heloisa Buarque de. Pensamento feminista: conceitos fundamentais. Rio de Janeiro: Bazar do Tempo, 2019. p. 121-156.

LOURO, Guacira Lopes. Flor de açafrão: takes Cuts Close-ups. Belo Horizonte: Autêntica, 2017.

MARCELLO, Fabiana de Amorim. O conceito de dispositivo em Foucault: mídia e produção agonística de sujeitos-maternos. Revista Educação e Realidade, UFRGS, Porto Alegre, v. 29, n. 1, p. 199-213, jan./jun. 2004.

SALES, Shirlei Rezende. Juventude ciborgue. In: LIMA, Nádia Laguárdia de et al. Desafios para o currículo escolar. Belo Horizonte: Quixote+Do Editoras Associadas, 2018a. p. 83-95.

SALES, Shirlei Rezende. Juventude e sexualidade ciborgue no aplicativo de namoro de Black Mirror. In: RIBEIRO, Paula R. C. et al. Corpo, gênero e sexualidade: resistência e ocupa(ações) nos espaços de educação. Rio Grande: Editora da FURG, 2018b. p. 105-120.

SCOTT, Joan. Gênero: uma categoria útil de análise histórica. In: HOLLANDA, Heloisa Buarque de. Pensamento feminista: conceitos fundamentais. Rio de Janeiro: Bazar do Tempo, 2019. p. $49-82$. 